\title{
Study of immune responses in mice to oral administration of Flor-Essence
}

\author{
JINGXIN WU ${ }^{1 *}$, JIA LIU $^{2 *}$, CHAO QU $^{1,3}$, YUXIN WANG $^{1}$, YAN ZHU $^{1}$, YEJUN ZHANG $^{1,3}$, \\ HONGYAN LI ${ }^{1,3}$, BINGQIANG ZHANG ${ }^{4}$, YARU SUN ${ }^{4}$ and WEI ZOU ${ }^{1,3}$ \\ ${ }^{1}$ College of Life Science, Liaoning Normal University, Dalian, Liaoning $116081 ;{ }^{2}$ School of Life Science and Biotechnology, \\ Faculty of Chemical, Environmental and Biological Science and Technology, Dalian University of Technology, Dalian, \\ Liaoning 116024; ${ }^{3}$ Liaoning Key Laboratories of Biotechnology and Molecular Drug Research and Development, \\ Dalian, Liaoning 116029; ${ }^{4}$ Qingdao Ruiside Biotechnology Co., Ltd., Qingdao, Shandong 266111, P.R. China
}

Received April 15, 2019; Accepted November 18, 2019

DOI: $10.3892 / \mathrm{mco} .2020 .2023$

\begin{abstract}
Flor:Essence(FE), anaturalfood gradeherbalformula product manufactured by Flora Manufacturing \& Distributing Ltd., has been used by patients with cancer in North America to stimulate immune cells in order to attenuate or reverse immune damage. To elucidate the mechanisms underlying the effects of FE on the immune system, spleen lymphocyte proliferation was analyzed by an MTT assay, and the phagocytic capacity of macrophages was measured via the neutral red phagocytosis method. The cytotoxicity of natural killer (NK) cells towards K562 cells was assessed via a CytoTox 96 assay. The production of the cytokines interleukin (IL)-12 and interferon (IFN)- $\gamma$ in the peripheral blood was determined via ELISA and PCR analysis. The expression levels of caveolin-1 and NF- $\mathrm{NB}$ were measured via western blotting. In addition, cyclophosphamide was used to establish a mouse model of immunosuppression. It was found that the proliferation of splenocytes, the phagocytic capacity of macrophages and the cytotoxicity of NK cells against K562 cells were increased after oral administration of FE to mice. FE augmented the production of IL-12 and IFN- $\gamma$ in the peripheral blood of mice. FE significantly increased the expression of proliferating cell nuclear antigen and caveolin-1, and decreased NF- $\mathrm{NB}$ expression. Finally, FE enhanced the viability of immune cells from cyclophosphamide-treated immunosuppressed mice. The results indicated that FE could activate immune responses and enhance natural immunity, suggesting that oral administration of FE can activate the body's immune response and resist damage caused by cyclophosphamide chemotherapy.
\end{abstract}

Correspondence to: Professor Wei Zou, College of Life Science, Liaoning Normal University, 3 Teaching Building, 1 Liushunanjie, Dalian, Liaoning 116081, P.R. China

E-mail: weizou60@126.com

*Contributed equally

Key words: Flor-Essence, natural killer cell, splenocytes, immunity cytokines, immunity ability

\section{Introduction}

Malignant tumors are amongst the leading causes of human mortality (1). The current methods of treating tumors are predominantly radiotherapy and chemotherapy, which improve the therapeutic outcomes of patients with malignant tumors; however, the side effects are a major obstacle in some patients (2).

Numerous patients who do not respond to traditional therapies frequently seek adjuvant and alternative medical treatments in the hope of reducing tumor size and enhancing immunity (3). In Western high-income countries, the use of complementary and alternative medicine (CAM) in patients with cancer is as high as $91 \%(4,5)$. Immunostimulants can enhance the body's immunity, and one of the research directions of CAM is to find safe and effective immune stimulants that can be used in clinical practice to prevent diseases $(6,7)$.

Flor-Essence (FE) Tonics is a complex mixture of commercially available herbal extracts, and is sold as a dietary supplement and used by patients with cancer due to reports that it may aid in treating or preventing disease (8). Large quantities of supplements are shipped to the US and Canada annually, primarily for use in cancer treatment (9-13).

FE contains eight different types of herb, which predominantly contain phenolics. The FE formula is proprietary; however, the composition in descending order of magnitude is as follows: i) Burdock root; ii) sheep sorrel herb; iii) slippery elm bark; iv) watercress herb; v) kelp; vi) blessed thistle herb; vii) red clover herb; and viii) Turkish rhubarb root (14). It has been reported that kelp may reduce the incidence of cancer by affecting oxidative activity, specifically in liver cancer and lung cancer $(15,16)$. Arctigenin inhibits mitogen-activated protein kinases, including ERK1/2, p38 kinase and JNK, resulting in an increase in the activity of NAPDH oxidase 2, tumor necrosis factor- $\alpha(\mathrm{TNF}-\alpha)$ and transforming growth factor- $\beta 1$ (17). Dietary isoflavones inhibit the progression of prostate cancer by inducing apoptosis in tumor cells (18). It has been reported FE has various positive functions, including antioxidant, antiestrogen, immunostimulatory and antitumor effects $(8,19,20)$. Cheung et al (20) reported that FE inhibited nitric oxide (NO) production in a concentration-dependent 
manner in lipopolysaccharide (LPS)-stimulated RAW 264.7 cells. Reverse transcription-quantitative PCR assays revealed that FE induced the expression of IL-1 $\beta$, inducible nitric oxide synthase and cyclooxygenase-2 in RAW 264.7 cells.

In the present study, an immunosuppressive mouse model was established using cyclophosphamide (CP) to explore the effects of FE on the side effects of chemotherapy.

\section{Materials and methods}

Sample preparation. FE was obtained from Shenzhen Fulan Trading Co., Ltd. (Flora Manufacturing \& Distributing, Ltd.). FE was boiled with distilled water overnight in a small bowl. Samples were filtered with a $200-\mu$ m nylon mesh. Then, it was cooled and refrigerated at $4^{\circ} \mathrm{C}$. Concentration of 10,20 and $40 \mathrm{mg} / \mathrm{kg} \mathrm{FE}$ were prepared for oral administration in mice.

Animals and supplementation with FE. Specific pathogen-free Kunming mice (male, 6-8 weeks old, 18-22 g) were supplied by the Experimental Animal Center of Dalian Medical University. The mice were housed under standard laboratory conditions $\left(25^{\circ} \mathrm{C}, 40-60 \%\right.$ relative humidity, under a $12: 12 \mathrm{~h}$ light/dark cycle) and were fed with standard rodent food and water ad libitum. Mice were monitored and weighed daily. A total of 80 mice were randomly divided (20/group) into control group (saline), low-dose FE group (10 mg/kg), medium-dose group $(20 \mathrm{mg} / \mathrm{kg})$ and high-dose group $(40 \mathrm{mg} / \mathrm{kg})$. FE was administered via gavage twice daily for 5 weeks.

Measurement of immune organs and weight. Mice were sacrificed by $\mathrm{CO}_{2}$ asphyxiation after a final weight measurement ( 3 mice/group). The spleen and thymus were removed aseptically, dried and weighed. The organ index was calculated as follows: Thymus index $=$ thymic weight $(\mathrm{mg}) / \mathrm{animal}$ weight $(\mathrm{g}) \times 100 \%$; spleen index $=$ spleen weight $(\mathrm{mg}) / \mathrm{animal}$ weight $(\mathrm{g}) \times 100 \%$.

Spleen lymphocyte isolation. Spleens were aseptically removed and homogenized through $200-\mu$ m nylon mesh (three mice per group). To prepare a single cell suspension, red blood cell lysate (Beijing Solarbio Science \& Biotechnology Co., Ltd.) was added, allowed to stand for $8 \mathrm{~min}$, and centrifuged at $800 \mathrm{x} \mathrm{g}$ for $30 \mathrm{~min}$ at room temperature. The lymphocyte layer was aspirated and resuspended in RPMI-1640 (Gibco; Thermo Fisher Scientific, Inc.) for density gradient centrifugation at $250 \mathrm{x}$ g for $10 \mathrm{~min}$ at room temperature. The cells were cultured in RPMI-1640 supplemented with 10\% FBS (cat. no. 10099141; Gibco, Thermo Fisher Scientific, Inc.). All cells were maintained in a humidified atmosphere at $37^{\circ} \mathrm{C}$ in $5 \% \mathrm{CO}_{2}$.

MTT assay for cell viability. Each group of mouse spleen cells were seeded at $4 \times 10^{4} /$ well in 96 -well plates and cultured in RPMI-1640 supplemented with $10 \% \mathrm{FBS}$ at $37^{\circ} \mathrm{C}$ with 5\% $\mathrm{CO}_{2}$. LPS (100 $\mu \mathrm{g} / \mathrm{ml}$; cat. no. L2630; Sigma-Aldrich; Merck KGaA) was added to the culture medium for $24 \mathrm{~h}$, following which MTT reagent $(5 \mathrm{mg} / \mathrm{ml}$; cat. no. V13154; Gibco; Thermo Fisher Scientific, Inc.) was added to the cell medium and cells were incubated at $37^{\circ} \mathrm{C}$ for an additional $4 \mathrm{~h}$. The reaction was terminated with $150 \mu \mathrm{l} /$ well DMSO and the cells were lysed for $15 \mathrm{~min}$, with the plates agitated every $5 \mathrm{~min}$. Absorbance values were determined using a microplate reader at $492 \mathrm{~nm}$.

Peritoneal cell isolation. Mice were fasted for $>8 \mathrm{~h}$ before surgery, and mice were sacrificed by $\mathrm{CO}_{2}$ asphyxiation ( 3 mice/group). The mice were soaked for $3 \mathrm{~min}$, the skin was cut open and the peritoneum was fully exposed. Pre-cooled 1640 medium $(5 \mathrm{ml})$ was intraperitoneally injected, and the abdomen of the mouse was incubated for $5 \mathrm{~min}$. The peritoneal lavage fluid was withdrawn by a syringe and collected in a $15-\mathrm{ml}$ centrifuge tube; this was repeated twice. The supernatant was centrifuged at $4^{\circ} \mathrm{C}$ and $450 \mathrm{xg}$ for $8 \mathrm{~min}$, and red blood cell lysate was added until a white cell pellet was observed. The cells were cultured in RPMI-1640 supplemented with $10 \%$ FBS, and then seeded into 96-well culture plates. Cells were maintained in a humidified atmosphere at $37^{\circ} \mathrm{C}$ in $5 \% \mathrm{CO}_{2}$.

Phagocytosis neutral red method. Peritoneal macrophages were obtained, $4 \%$ trypan blue was mixed with cells at a concentration of 9:1 at room temperature (final concentration, $0.04 \%$ ), and cells counted after $\sim 3$ min and incubated at $37^{\circ} \mathrm{C}$ for $2 \mathrm{~h}$ to allow cells to adhere. The cells were washed twice with D-Hanks solution (Beijing Solarbio Science \& Biotechnology Co., Ltd.) to remove unattached cells. Neutral red $(100 \mu \mathrm{l})$ was added to each well, and after $4 \mathrm{~h}$ at $37^{\circ} \mathrm{C}$, wells were washed 3 times with D-Hanks solution. After adding $100 \mu 1$ of cell lysate, after $30 \mathrm{~min}$, the optical density (OD) value of each well was measured at $490 \mathrm{~nm}$ by a microplate reader.

Semi-quantitative PCR. TRIzol ${ }^{\circledR}$ (Invitrogen; Thermo Fisher Scientific, Inc.) reagent was used to extract total RNA from spleen lymphocytes. Then, a ProtoScript II RT-PCR kit (Takara Biotechnology Co., Ltd.) (21) was used to reverse transcribe RNA. qPCR analysis of interferon (IFN)- $\alpha$, IFN- $\beta$ and GAPDH was conducted using the following gene-specific primers: IFN- $\alpha$, forward, 5'-ATGAGCACTGAAAGCATGATC-3' and reverse, 5'-TCACAGGGCAATGATCCCAAAGTAGACCTG CCC-3'; IFN- $\beta$, forward, 5'-CTTGAATTCACTGCTCTC CTG-3' and reverse, 5'-CGGCTCGAGTCAGTTAGGGAG-3'; GAPDH, forward, 5'-CTAGCACCCCTGGCCAAG-3' and reverse, 5'-GATGTTCTGGAGAGCCCCG-3'. PCR was conducted as follows: An initial denaturation step at $94^{\circ} \mathrm{C}$ for $5 \mathrm{~min}$, followed by 30 cycles of annealing for $30 \mathrm{sec}, 53^{\circ} \mathrm{C}$ for $30 \mathrm{sec}$ and $72^{\circ} \mathrm{C}$ for $20 \mathrm{sec}$, and a final extension step at $72^{\circ} \mathrm{C}$ for $10 \mathrm{~min}$. PCR products were resolved via $1 \%$ agarose electrophoresis and visualized using ethidium bromide. Quantitative analysis was performed using ImageQuant TL 7.0 software (GE Healthcare Life Sciences).

Lactate dehydrogenase ( $L D H)$ assay of the viability of natural killer (NK) cells. Mice were sacrificed by $\mathrm{CO}_{2}$ asphyxiation and soaked in $75 \%$ ethanol, and the spleens of the mice were removed (3 mice/group). Mouse $1 \mathrm{X}$ lymphocyte separation solution (4-5 ml; cat. no. P8620; Beijing Solarbio Science \& Technology Co., Ltd.) was added to the culture dish for grinding. Immediately, the lymphocyte supernatant containing the spleen cells was transferred to a $15-\mathrm{ml}$ centrifuge tube, 200-500 $\mu 1$ of RPMI-1640 medium was added 
(maintaining a clear liquid boundary), the lymphocyte layer was aspirated and a further $10 \mathrm{ml}$ of RPMI-1640 medium was added. The solution was centrifuged at $800 \mathrm{x}$ g for $30 \mathrm{~min}$ at room temperature. The cells were collected via further centrifugation at $250 \mathrm{x} \mathrm{g}$ for $10 \mathrm{~min}$ at room temperature. The supernatant was decanted and the cells were cultured in RPMI-1640 supplemented with $10 \%$ FBS. Cells were maintained in a humidified atmosphere at $37^{\circ} \mathrm{C}$ in $5 \% \mathrm{CO}_{2}$.

The cytotoxicity of NK cells towards K562 cells (cat. no. BNCC339825; BeNa Culture Collection) was evaluated via co-culture (50:1) under standard conditions for $24 \mathrm{~h}$ at $37^{\circ} \mathrm{C}$ in $5 \% \mathrm{CO}_{2}$, followed by using a CytoTox $96^{\circledR} \mathrm{LDH}$ assay kit according to the manufacturer's protocol (cat. no. A020-2-2; Nanjing Jiancheng Bio-Engineering Institute Co., Ltd.).

The percentage of cytotoxicity was calculated using the formula below:

$\%$ Cytotoxicity $=\left(\mathrm{OD}_{\text {sample }}-\mathrm{OD}_{\text {contrast }}\right) /\left(\mathrm{OD}_{\text {standard }}-\mathrm{OD}_{\text {blank }}\right) \times 100$

Measurement of cytokines. The expression of IL-12, IFN- $\gamma$, IL-2 and TNF- $\alpha$ was measured using double antibody sandwich ELISA kits (IL-12, cat. no. BMS6004; IFN- $\gamma$, cat. no. BMS228; IL-2, cat. no. BMS601; TNF- $\alpha$, cat. no. BMS607-3; all from Invitrogen; Thermo Fisher Scientific, Inc.). During euthanasia, blood $(0.5 \mathrm{ml})$ was collected from each mouse (3 mice/group) via retro-orbital sampling, allowed to stand at room temperature for $2 \mathrm{~h}$ and at $4^{\circ} \mathrm{C}$ for $3-4 \mathrm{~h}$, centrifuged at $800 \mathrm{x}$ g for $5 \mathrm{~min}$ at room temperature and stored at $-20^{\circ} \mathrm{C}$. The supernatant from each group was collected, and their levels were quantitated by ELISA according to the manufacturer's protocols.

Western blot analysis. Spleens were aseptically removed and homogenized through 200- $\mu \mathrm{m}$ nylon mesh. Equal quantities (100 $\mu \mathrm{g} /$ lane) of spleen protein were analyzed via western blot analysis as previously described (22). Membranes were incubated with primary antibodies at $4^{\circ} \mathrm{C}$ overnight, and secondary antibodies [horseradish peroxidase-conjugated goat anti-rabbit and anti-mouse $\operatorname{IgG}(1: 8,000$; cat. nos. TA140003 and TA130003, respectively; OriGene Technologies, Inc.)] at room temperature for $1 \mathrm{~h}$. The following primary antibodies were used: Anti-caveolin-1 (Cav-1; mouse monoclonal; 1:1,000; cat. no. 03-6000; Invitrogen; Thermo Fisher Scientific, Inc.); anti-NF- $\kappa$ B (rabbit monoclonal; 1:1,000; cat. no. 8242T; Cell Signaling Technology, Inc.); anti-proliferating cell nuclear antigen (PCNA; mouse monoclonal; 1:500; cat. no. BM0104; Wuhan Boster Biological Technology, Ltd.); and anti- $\beta$-actin (mouse monoclonal; 1:1,000; cat. no. BM0627; Wuhan Boster Biological Technology, Ltd.). Bands were visualized using the BeyoECL Plus reagent (cat. no. P0018S; Beyotime Institute of Biotechnology) according to the manufacturer's protocols. Immunoblot data were quantified using ImageJ software (version 1.46; National Institutes of Health).

CP preparation of mouse model of immunosuppression. Specific pathogen-free Kunming mice (male, 6-8 weeks old, 18-22 g) were provided by the Experimental Animal Center of Dalian Medical University. A total of 90 mice were randomly divided (45/group) into a control group and $\mathrm{CP}$ group. The 45 mice in each group were randomized into 3 groups (15/group): Control group (saline), low-dose FE group $(10 \mathrm{mg} / \mathrm{kg}$ ) and high-dose FE group (40 mg/kg). Mice were intraperitoneally injected with physiological saline or $\mathrm{CP}$ (75 mg/mg; Beijing Solarbio Science \& Biotechnology Co., Ltd.) once every other day with $\mathrm{CP}$ for 8 days. At 8 days later, immunological indicators of the control and CP groups were measured to verify whether the immunocompromised mouse model was successfully constructed. Then, all mice were intragastrically administered with saline, or 10 or $40 \mathrm{mg} / \mathrm{kg}$ FE twice a day for 5 weeks, and the tissues were extracted on the last day.

Determination of the number of white blood cells. During euthanasia, blood $(0.5 \mathrm{ml})$ was collected from each mouse ( $3 \mathrm{mice} / g$ roup) via retro-orbital sampling, allowed to stand at room temperature for $2 \mathrm{~h}$ and at $4^{\circ} \mathrm{C}$ for $3-4 \mathrm{~h}$, centrifuged at $800 \mathrm{x} \mathrm{g}$ for $5 \mathrm{~min}$ at room temperature and stored at $-20^{\circ} \mathrm{C}$. Leukocyte diluent $(2.0 \mathrm{ml}$ glacial acetic acid, $1 \mathrm{ml} 1 \%$ gentian violet, $100 \mathrm{ml}$ distilled water) was prepared and filtered, and $0.19 \mathrm{ml}$ of this solution was added to $20 \mu \mathrm{l}$ peripheral blood using a hemoglobin pipette. The pipette was used to mix the blood and diluent thoroughly; the micropipette quickly absorbs the mixed suspensions, which was added to a counting cell. After standing for 2-3 min, the cell was microscopically examined; the total number of white blood cells in the four corner squares was counted using an optical inverted microscope (magnification, $\mathrm{x} 40$ ).

Statistical analyses. All data were expressed as the mean \pm SE. Unpaired Student's t-tests were used to analyze significant differences between the control and CP groups. Comparisons of multiple groups were analyzed using one- or two-way ANOVA followed by post hoc Tukey's test. $\mathrm{P}<0.05$ was considered to indicate a statistically significant difference.

\section{Results}

Effects of FE on immune organs, splenocytes and PCNA. The spleen and thymic indexes of the mice supplemented with FE were significantly higher than the control group following 5 weeks of supplementation (Fig. 1 A and B). In almost all rapidly proliferating cells, PCNA is important for DNA replication and cell cycle regulation, and is a key factor for measuring cell proliferation ability $(23,24)$. The effects of FE on proliferation in the immune organs were investigated by analyzing PCNA expression in splenocytes. The levels of PCNA in the mice administered with 10 or $40 \mathrm{mg} / \mathrm{kg}$ FE were significantly higher than in the control group (Fig. 1C). These results suggested that FE can enhance the viability of immune cells.

Effects of FE on immune cell activity and cytokine production. The macrophages obtained from mice which had been orally administered with FE had significantly increased phagocytic activity against neutral red (Fig. 2A). Mice supplemented with FE exhibited increased NK cytotoxicity compared with the control (Fig. 2B). In addition, FE also induced the production of IFN- $\alpha$ and IFN- $\beta$, which were evaluated via PCR. The data demonstrated that spleen lymphocytes from FE-supplemented mice expressed higher levels of IFN- $\alpha$ and IFN- $\beta$ than those from the controls (Fig. 2C). It was also shown that FE supplementation significantly increased the secretion of IL-12 and IFN- $\gamma$ into the blood (Fig. 2D). 

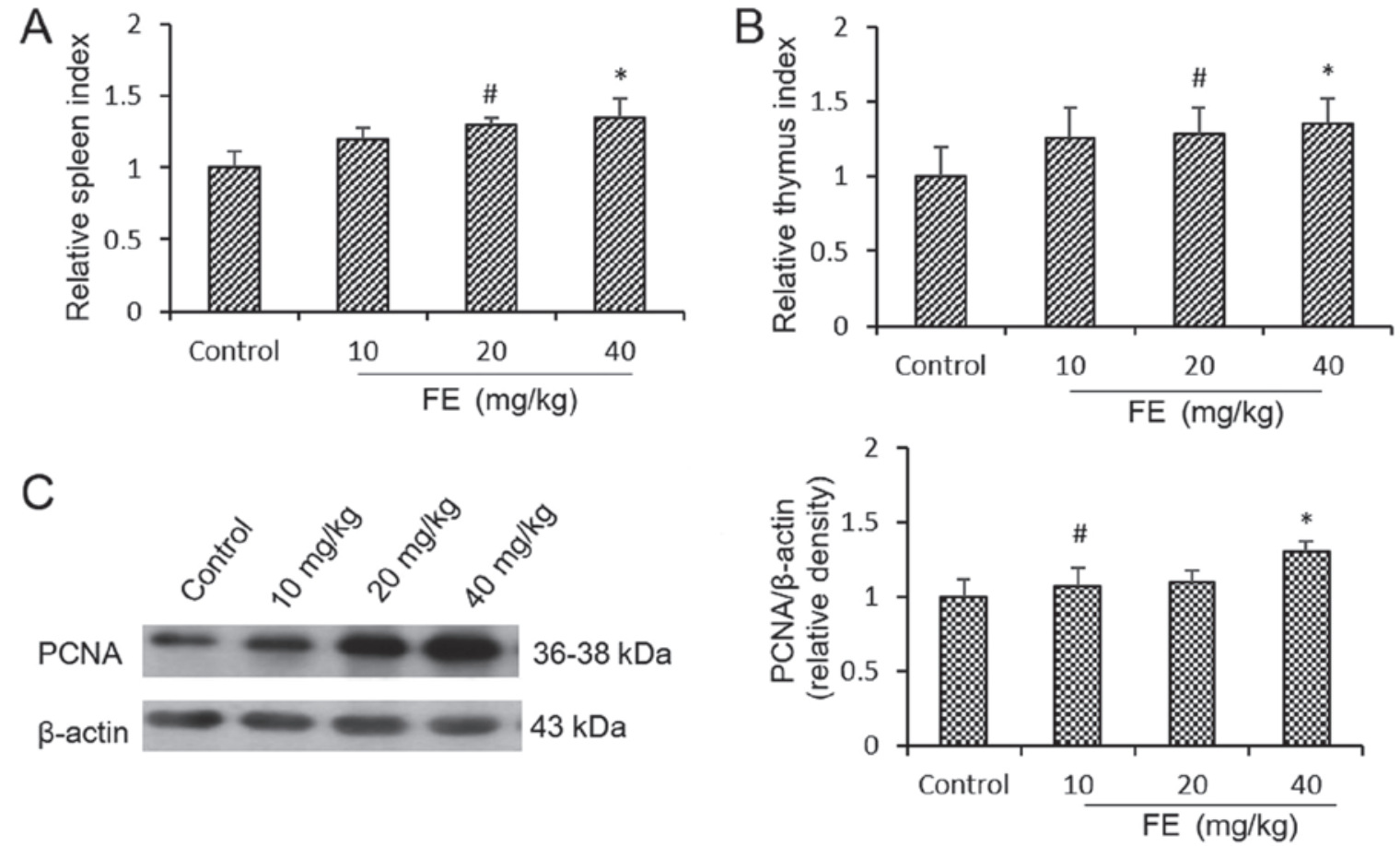

Figure 1. Effects of FE on the immune organs of mice. (A) Spleen index of mice receiving FE by gavage. (B) Thymus index of mice receiving FE by gavage. (C) PCNA levels were significantly higher in the mice that received $\mathrm{FE}$ compared with the control ( $\mathrm{n}=3$ ). " $\mathrm{P}<0.05$ and ${ }^{\text {"}} \mathrm{P}<0.05$ vs. Control. FE, Flor·Essence; PCNA, proliferating cell nuclear antigen.

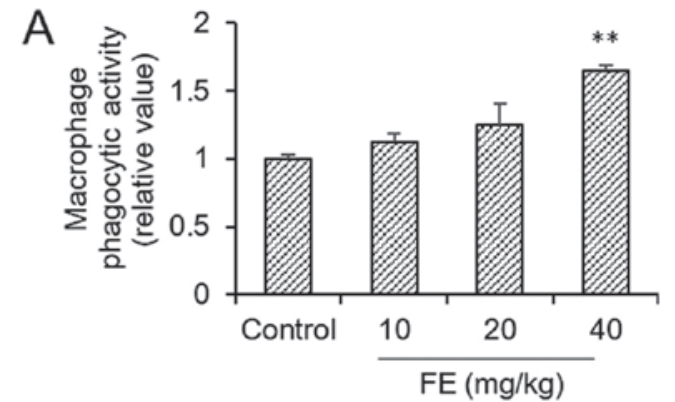

C
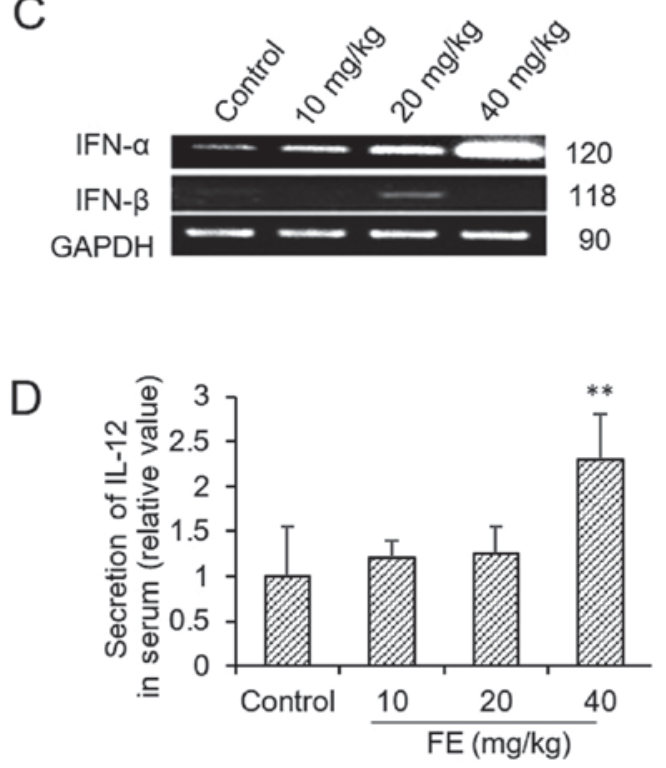
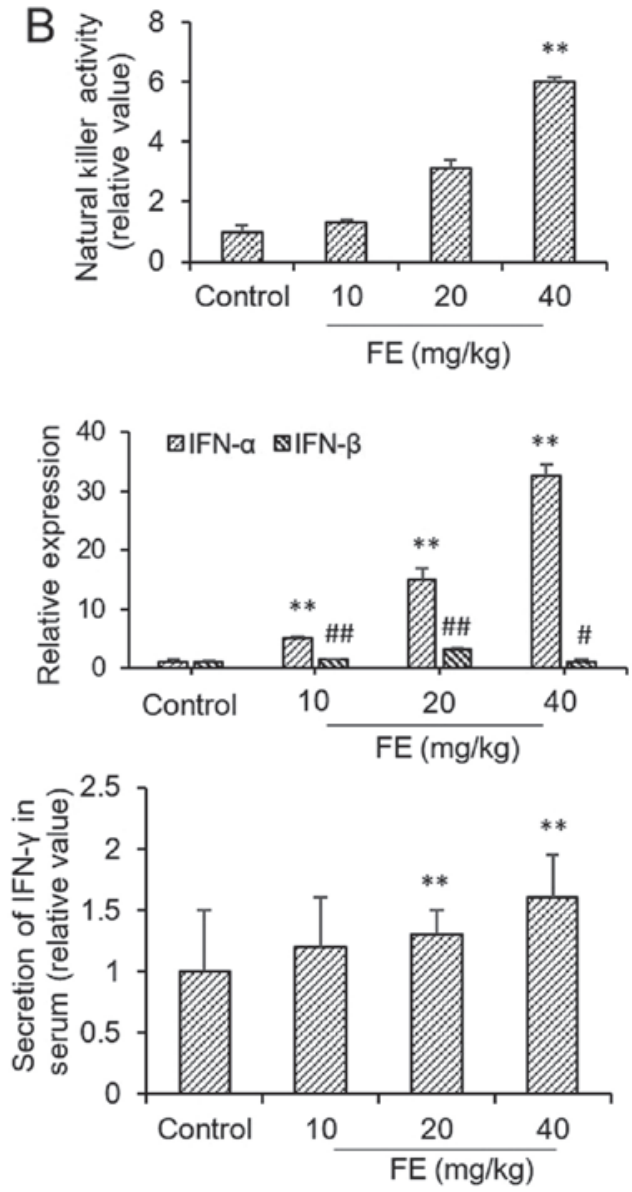

Figure 2. Effects of FE on immune cell activity and cytokine production. (A) Effects of FE on peritoneal macrophage phagocytosis in normal mice. (B) Effects of FE on natural killer cell activity in normal mice. (C) Effects of FE on the expression of IFN- $\alpha$ and IFN- $\beta$ as determined via PCR. (D) Effects of FE on the secretion of IL-12 and IFN- $\gamma$ in serum, as measured via ELISA. N=3. ${ }^{* *} \mathrm{P}<0.01$ vs. Control (IFN- $\alpha$ ); ${ }^{\#} \mathrm{P}<0.05$ and ${ }^{\# \#} \mathrm{P}<0.01$ vs. Control (IFN- $\beta$ ). FE, Flor $\cdot$ Essence; IL, interleukin; IFN, interferon. 
A

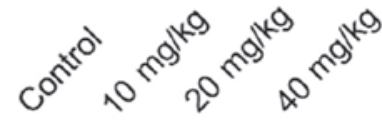

Cav-1

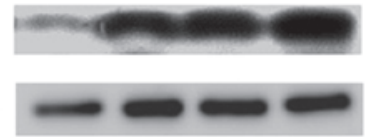

$22 \mathrm{kDa}$

$\beta$-actin

$43 \mathrm{kDa}$
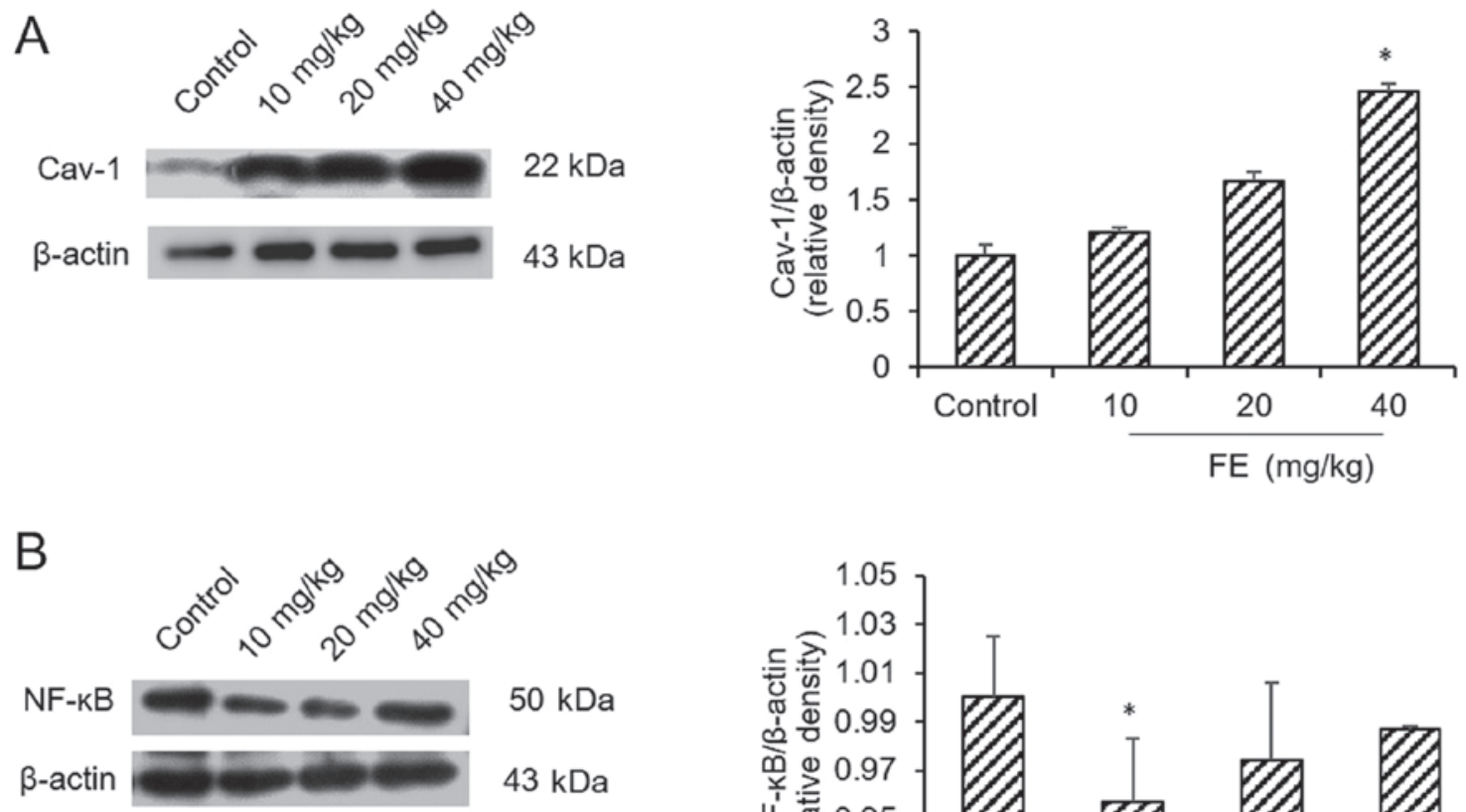

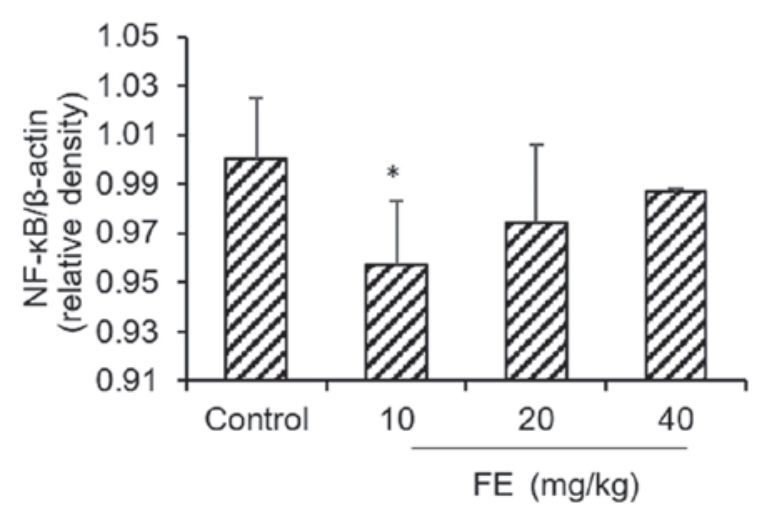

Figure 3. Effects of FE on the expression of Cav-1 and NF-kB. (A) Cav-1 levels as determined via western blotting. (B) NF-kB levels as determined via western blotting. N=3. ${ }^{*} \mathrm{P}<0.05$ vs. Control. FE, Flor-Essence; Cav-1, caveolin-1.

Effects of $F E$ on the expression of $N F-\kappa B$ and $C a v-1$. The results indicated that the mice supplemented with FE expressed more Cav-1 than the control mice (Fig. 3A). Additionally, it was demonstrated that the expression of NF- $\mathrm{\kappa B}$ was downregulated in $10 \mathrm{mg} / \mathrm{kg}$ FE group compared with the control (Fig. 3B).

Developing a mouse model of immunosuppression. CP was administered to mice via intraperitoneal injection every other day for 8 days (Fig. 4). Immunological parameters were measured, and immune damage and immunosuppression was observed. Compared with the control group, the white blood cell count, spleen index, and IL- 2 and TNF- $\alpha$ levels in serum were decreased significantly. This indicated that the immune function of $\mathrm{CP}$ group was compromised.

Effects of FE on immune cells in the mouse model of immunosuppression. The previous results obtained during the present study indicated that FE can increase the relative spleen size of mice, the phagocytic ability of peritoneal macrophages and the antitumor cytotoxicity of NK cells against K562 cells. To further investigate the effects of FE, a CP-induced model of immunosuppression was established, and the effects of treatment of these mice with FE on immune cell properties were analyzed.

The viability of spleen lymphocytes in control- or FE-treated normal mice and mice immunized with $\mathrm{CP}$ was detected. The results showed that the activity of spleen lymphocytes in the $\mathrm{CP}$ group was significantly decreased, and low $(10 \mathrm{mg} / \mathrm{kg})$ and high $(40 \mathrm{mg} / \mathrm{kg})$ concentrations of $\mathrm{FE}$ attenuated the effects of $\mathrm{CP}$ on cell viability. It was shown that FE could significantly increase the activity of spleen lymphocytes from immunosuppressed mice (Fig. 5A).

The phagocytic activity of peritoneal macrophages in normal mice and CP mice was detected. FE (10 and $40 \mathrm{mg} / \mathrm{kg}$ ) was used to promote the immune activity of mice. The results showed that the phagocytic ability of macrophages was significantly increased after oral FE administration (Fig. 5B).

The killing activity of NK cells in normal mice and CP mice was detected. NK cell killing ability of mice after oral administration of FE was detected. The results showed that the ability of NK cells to kill cancer cells was significantly increased after FE administration in normal and immunosuppressed mice (Fig. 5C).

\section{Discussion}

The effects of FE on immune cell activity and cytokine production were investigated. Neutral red is recognized as a foreign substance by macrophages, and the present findings showed that FE treatment increases the phagocytic activity of macrophages isolated from the peritoneum of mice. NK cells are lymphocytes associated with autoimmune conditions that form an early immune defense during innate immunity (25). It was previously reported that the number of NK cells was reduced in patients with non-small cell lung cancer and melanoma (26). Active hexose correlated compound (AHCC) is an edible fungal extract that can affect immune responses when ingested (27). In vivo and in vitro studies have reported that the immunomodulatory effects of AHCC enhance the activity of NK, $\mathrm{CD}^{+} \mathrm{T}$ and $\gamma \delta \mathrm{T}$ cells (27). The present study showed that 

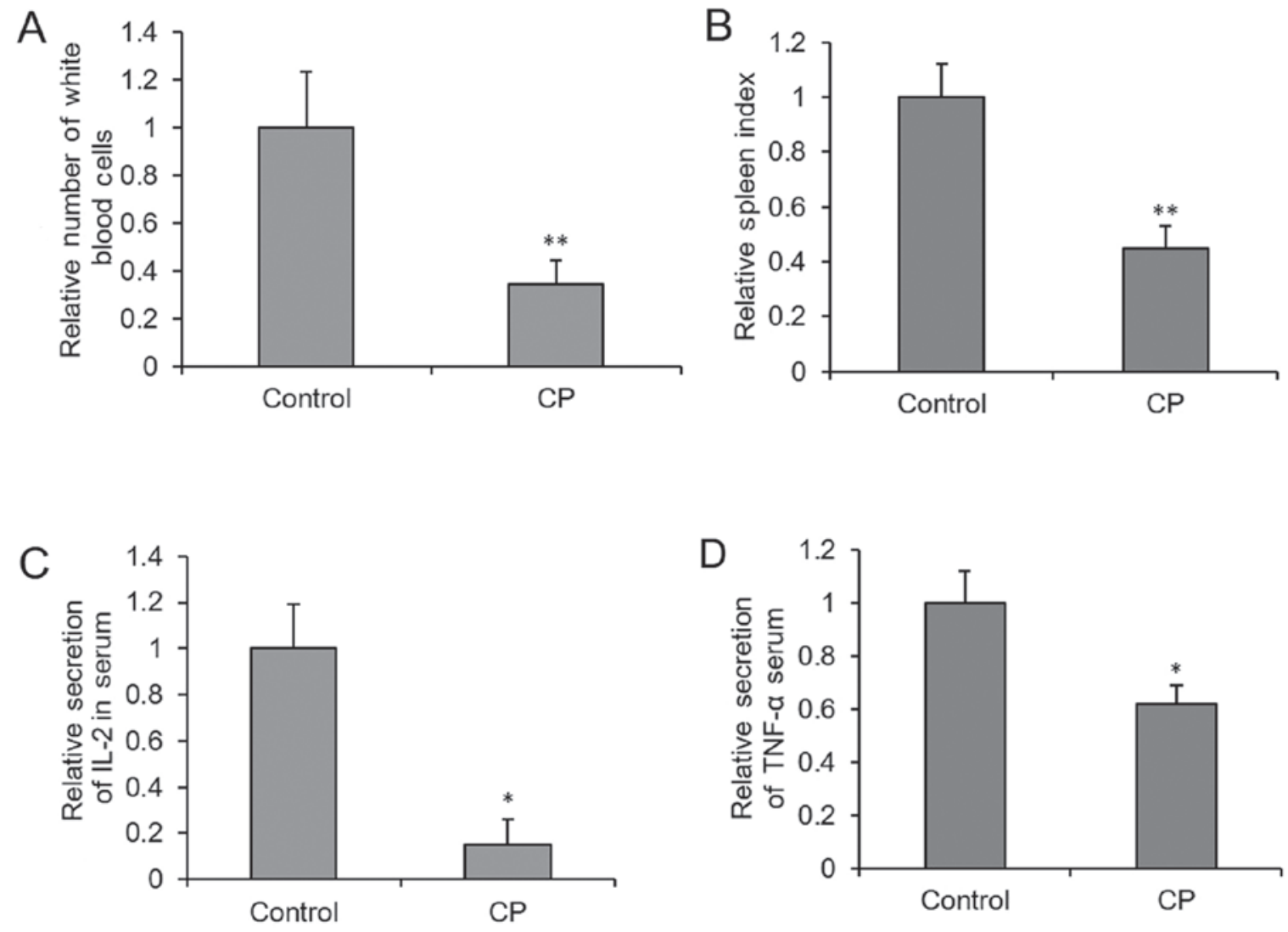

Figure 4. Developing a mouse model of immunosuppression. (A) Effects of $\mathrm{CP}$ on the number of white blood cells in mice. (B) Effects of CP on the spleen index of mice. (C) IL-2 protein levels were estimated by ELISA. (D) TNF- $\alpha$ protein levels were estimated by ELISA. ${ }^{*} \mathrm{P}<0.05$ and ${ }^{* *} \mathrm{P}<0.01$ vs. Control. N=3. $\mathrm{CP}$, cyclophosphamide; IL, interleukin; TNF, tumor necrosis factor.
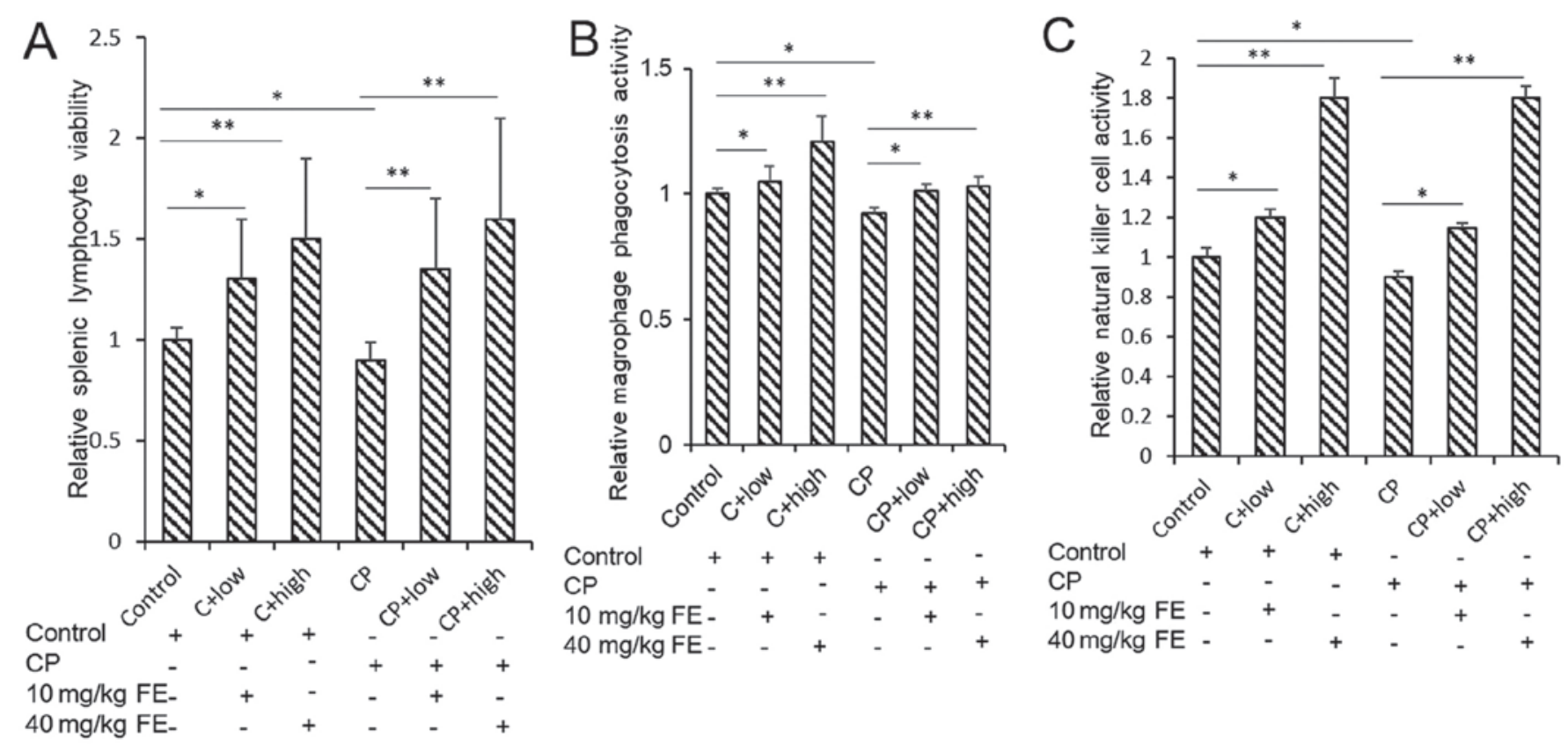

Figure 5. Effects of oral administration of FE in a mouse model of immunosuppression. (A) Effects of FE on the viability of spleen lymphocytes from immunosuppressed mice. (B) Effects of FE on the phagocytic activity of macrophages from immunosuppressed mice. (C) Effects of FE on the cytotoxic effects of natural killer cells against K562 cells. $\mathrm{N}=3$. ${ }^{*} \mathrm{P}<0.05$ and ${ }^{* *} \mathrm{P}<0.01$. FE, Flor Essence; $\mathrm{CP}$, cyclophosphamide; $\mathrm{C}$, Control.

FE can enhance the killing ability of mouse NK cells, indicating that FE promotes innate immune responses. There is a strong association between NK activity and changes in spleen cells (28). In addition, FE also induced the production of IFN- $\alpha$ and IFN- $\beta$ as determined via semi-quantitative PCR analysis. The data demonstrated that FE-supplemented mice exhibited 
greater IFN- $\alpha$ and IFN- $\beta$ mRNA expression than control mice. IFN- $\alpha$ and IFN- $\beta$ can activate NK cells, induce antiviral states and inhibit viral republication, which are important for host defenses against viruses (29). IL-12 is a stimulating factor of NK cells, inducing the production of IFN and TNF, and activating NK cells to stimulate their differentiation, enabling NK cells to produce more TNF- $\alpha$; therefore, IL-12 and TNF- $\alpha$ are associated with adaptive immunity (30-32). IFN- $\gamma$ is an important component of the body's immune system, and is produced by activated T cells and NK cells (33). It can effectively resist viral infection and tumor formation, and promote the body's immune response (34). Therefore, IL-12 and IFN- $\gamma$ levels were evaluated in peripheral blood via ELISA. Results showed that FE-supplemented mice exhibited increased secretion of IFN- $\gamma$ and IL-12.

FE has previously been reported to enhance cell inflammation. Cheung et al (20) reported that FE inhibits NO production in a concentration-dependent manner in LPS-stimulated RAW 264.7 cells. Long et al (35) reported that ovarian cancer stem cells upregulate chemokine ligand 5 and activate $\mathrm{NF}-\kappa \mathrm{B}$ signaling through autocrine signaling, and induce tumor metastasis. Inhibiting the key inflammatory transcription factor $\mathrm{NF}-\kappa \mathrm{B}$ may suppress tumor invasion (36). NF- $\mathrm{NB}$ is associated with cancer, and is located downstream of the oncogenes Ras, Myc and Ret (37). In addition, NF- $\kappa \mathrm{B}$ plays a key role in connecting inflammation with cancer (38). In the present study, it was demonstrated that expression of $\mathrm{NF}-\kappa \mathrm{B}$ was downregulated in animals supplemented with FE, suggesting that FE may dampen inflammation through $\mathrm{NF}-\kappa \mathrm{B}$.

Cav-1, a structural protein of the cell membrane, is involved in tissue homeostasis, inflammation, oxidative stress, microbial clearance, and fibrosis (39). Cav-1 serves an important role in regulating inflammatory cell signaling in leukocytes (40). A previous study reported interactions between Cav-1 and Toll-like receptor 4 , as detected by immunofluorescence in MCF-10A and MCF-10ACE cells (40). This interaction may influence the downstream regulation of inflammation-associated gene expression (41). Therefore, the expression of inflammation-related protein $\mathrm{Cav}-1$ was analyzed. The results indicated that the mice supplemented with FE expressed more Cav-1 than the mice without FE, suggesting that FE may suppress inflammation via enhanced Cav-1 expression.

In the present study, increases in the proliferation of splenocytes, phagocytosis of macrophages and cytotoxicity of NK cells towards K562 cells were observed following FE treatment in a mouse model of CP-induced immunosuppression. The mechanism of $\mathrm{CP}$-induced immunosuppression is similar to that of nitrogen mustard (42). CP is crosslinked with DNA to inhibit the synthesis of DNA and interfere with RNA function, inhibit tumor growth; however, when killing tumor cells, CP can damage the immune organs and inhibit humoral immunity (43). The enhancement effects of FE against immunosuppression suggested that FE may be effective as an adjuvant to chemotherapy or for use in patients with reduced immune function.

\section{Acknowledgements}

Not applicable.

\section{Funding}

This study was supported by Scientific and Technological Developing Scheme of Ji Lin Province, Liaoning Provincial Natural Science Foundation (grant no. 2015020568) and Liaoning Provincial Department of Education Research Project (grant no. L201783647)

\section{Availability of data and materials}

The datasets used and/or analyzed during the current study are available from the corresponding author on reasonable request.

\section{Authors' contributions}

JW, JL and CQ were involved in conceiving the study, acquiring and analyzing the data, and writing the original draft. YW, YZhu, YZha and HL were involved in designing the study and analyzing the data. BZ and YS analyzed data. WZ designed the project, and acquired funding and resources. All authors read and approved the final manuscript.

\section{Ethics approval and consent to participate}

The study was approved by the Ethics Committee of Liaoning Normal University.

\section{Patient consent for publication}

Not applicable.

\section{Competing interests}

The authors declare that they have no competing interests.

\section{References}

1. Yuan P, Chen TH, Chen ZW and Lin XQ: Calculation of life-time death probability due malignant tumors based on a sampling survey area in China. Asian Pac J Cancer Prev 15: 4307-4309, 2014.

2. Tai J, Cheung S, Wong S and Lowe C: In vitro comparison of Essiac and Flor-Essence on human tumor cell lines. Oncol Rep 11: 471-476, 2004.

3. Nejatian M, Alami A, Tehrani H, Lael-Monfared E and Jafari A: Perceptions and personal use of complementary and alternative medicine (CAM) by Iranian health care providers. Complement Ther Clin Pract 32: 145-150, 2018.

4. Kuo YH, Tsay SL, Chang CC, Liao YC and Tung HH: Cancer impact, complementary/alternative medicine beliefs, and quality of life in cancer patients. J Altern Complement Med 24: 276-281, 2018.

5. Farooqui M, Hassali MA, Shatar AK, Farooqui MA, Saleem F, Haq NU and Othman CN: Use of complementary and alternative medicines among Malaysian cancer patients: A descriptive study. J Tradit Complement Med 6: 321-326, 2015.

6. Hunault J, Diswall M, Frison JC, Blot V, Rocher J, Marionneau-Lambot S, Oullier T, Douillard JY, Guillarme S, SaluzzoC, et al:3-Fluoro-and3,3-difluoro-3,4-dideoxy-KRN7000 analogues as new potent immunostimulator agents: Total synthesis and biological evaluation in human invariant natural killer T cells and mice. J Med Chem 55: 1227-1241, 2012.

7. Yeap SK, Omar AR, Ho WY, Beh BK, Ali AM and Alitheen NB: Rhaphidophora korthalsii modulates peripheral blood natural killer cell proliferation, cytokine secretion and cytotoxicity. BMC complement Altern Med 13: 145, 2013. 
8. Kulp KS, Montgomery JL, Nelson DO, Cutter B, Latham ER, Shattuck DL, Klotz DM and Bennett LM: Essiac and Flor-Essence herbal tonics stimulate the in vitro growth of human breast cancer cells. Breast Cancer Res Treat 98: 249-259, 2006.

9. Richardson MA, Sanders T, Palmer JL, Greisinger A and Singletary SE: Complementary/alternative medicine use in a comprehensive cancer center and the implications for oncology. J Clin Oncol 18: 2505-2514, 2000.

10. Seely D, Kennedy DA, Myers SP, Cheras PA, Lin D, Li R Cattley T, Brent PA, Mills E and Leonard BJ: In vitro analysis of the herbal compound Essiac. Anticancer Res 27: 3875-3882, 2007.

11. Song J, Li N, Xia Y, Gao Z, Zou SF, Yan YH, Li SH, Wang Y, Meng YK, Yang JX, et al: Arctigenin confers neuroprotection against mechanical trauma injury in human neuroblastoma SH-SY5Y cells by regulating miRNA-16 and miRNA-199a expression to alleviate inflammation. J Mol Neurosci 60: 115-129, 2016.

12. Moy KA, Yuan JM, Chung FL, Wang XL, Van Den Berg D, Wang R, Gao YT and Yu MC: Isothiocyanates, glutathione S-transferase M1 and T1 polymorphisms and gastric cancer risk: A prospective study of men in Shanghai, China. Int J Cancer 125 2652-2659, 2009

13. Solanky KS, Bailey NJ, Beckwith-Hall BM, Bingham S, Davis A, Holmes E, Nicholson JK and Cassidy A: Biofluid 1H NMR-based metabonomic techniques in nutrition research - metabolic effects of dietary isoflavones in humans. J Nutr Biochem 16: 236-244, 2005.

14. Lin $\mathrm{H}, \mathrm{He} \mathrm{YH}, \mathrm{Xu} \mathrm{R}$ and Zou W: Effect of Flor-Essence on serum levels of IL-6, IL-12, TNF- $\alpha$ and NK cells in exercise rats. Sheng Li Xue Bao 67: 618-622, 2015 (In Chinese).

15. Zhu Q, Chen J, Li Q, Wang T and Li H: Antitumor activity of polysaccharide from Laminaria japonica on mice bearing $\mathrm{H} 22$ liver cancer. Int J Biol Macromol 92: 156-158, 2016.

16. Mei C, Zhou S, Zhu L, Ming J, Zeng F and Xu R: Antitumor effects of Laminaria extract fucoxanthin on lung cancer. Mar Drugs 15: E39, 2017.

17. Lu Z, Chang L, Du Q, Huang Y, Zhang X, Wu X, Zhang J, Li R, Zhang Z,Zhang W,et al: Arctigenin induces an activation response in porcine alveolar macrophage through TLR6-NOX2-MAPKs signaling pathway. Front Pharmacol 9: 475, 2018.

18. Sivoňová MK, Kaplán $P$, Tatarková Z, Lichardusová L, Dušenka R and Jurečeková J: Androgen receptor and soy isoflavones in prostate cancer. Mol Clin Oncol 10: 191-204, 2019.

19. Tamayo C, Richardson MA, Diamond S and Skoda I: The chemistry and biological activity of herbs used in Flor-Essence herbal tonic and Essiac. Phytother Res 14: 1-14, 2000.

20. Cheung S, Lim KT and Tai J: Antioxidant and anti-inflammatory properties of ESSIAC and Flor-Essence. Oncol Rep 14 $1345-1350,2005$.

21. Qu C, Ma J, Zhang Y, Han C, Huang L, Shen L, Li H, Wang X, Liu J and Zou W: Estrogen receptor variant ER- $\alpha 36$ promotes tamoxifen agonist activity in glioblastoma cells. Cancer Sci 110 : 221-234, 2019

22. Qu C, Sun J, Liu Y, Wang X, Wang L, Han C, Chen Q, Guan T, Li H, Zhang Y, et al: Caveolin-1 facilitated KCNA5 expression, promoting breast cancer viability. Oncol Lett 16: 4829-4838, 2018 .

23. Strzalka W and Ziemienowicz A: Proliferating cell nuclear antigen (PCNA): A key factor in DNA replication and cell cycle regulation. Ann Bot 107: 1127-1140, 2011.

24. Zhao H, Lo YH, Ma L, Waltz SE, Gray JK, Hung MC and Wang SC: Targeting tyrosine phosphorylation of PCNA inhibits prostate cancer growth. Mol Cancer Ther 10: 29-36, 2011.

25. Göbel TW, Kaspers B and Stangassinger M: NK and T cells constitute two major, functionally distinct intestinal epithelial lymphocyte subsets in the chicken. Int Immunol 13: 757-762, 2001.

26. Al Omar SY, MarshallE, Middleton D and Christmas SE: Increased killer immunoglobulin-like receptor expression and functional defects in natural killer cells in lung cancer. Immunology 133: 94-104, 2011
27. Lee WW, Lee N, Fujii H and Kang I: Active hexose correlated compound promotes T helper (Th) 17 and 1 cell responses via inducing IL-1 $\beta$ production from monocytes in humans. Cell Immunol 275: 19-23, 2012.

28. Chen L, Zhu SL and Cao M: Protective effect of orgnoselenium from Se-enriched lactobacillus on lipid peroxidation reaction and NK cell activity in spleen of liver injury mice. Shi Yan Sheng Wu Xue Bao 38: 1-6, 2005 (In Chinese).

29. Nguyen KB, Salazar-Mather TP, Dalod MY, Van Deusen JB, Wei XQ, Liew FY, Caligiuri MA, Durbin JE and Biron CA Coordinated and distinct roles for IFN-alpha beta, IL-12, and IL-15 regulation of NK cell responses to viral infection. J Immunol 169: 4279-4287, 2002.

30. Ritz BW, Aktan I, Nogusa S and Gardner EM: Energy restriction impairs natural killer cell function and increases the severity of influenza infection in young adult male C57BL/6 mice. J Nutr 138: 2269-2275, 2008 .

31. García-Sastre A and Biron CA: Type 1 interferons and the virus-host relationship: A lesson in détente. Science 312: 879-882, 2006.

32. Trinchieri G: Interleukin-12 and the regulation of innate resistance and adaptive immunity. Nat Rev Immunol 3: 133-146, 2003.

33. Zhao X, Wei $Y$ and Kariya $Y$ : Induction of antitumor immune response by NK-cell-sensitive target cells transfected by B7-1 gene. Zhonghua Yi Xue Yi Chuan Xue Za Zhi 15: 210-213, 1998 (In Chinese).

34. Fuchs A, Vermi W, Lee JS, Lonardi S, Gilfillan S, Newberry RD, Cella $\mathrm{M}$ and Colonna $\mathrm{M}$ : Intraepithelial type 1 innate lymphoid cells are a unique subset of IL-12- and IL-15-responsive IFN- $\gamma$-producing cells. Immunity 38: 769-781, 2013.

35. Long H, Xie R, Xiang T, Zhao Z, Lin S, Liang Z, Chen Z and Zhu B: Autocrine CCL5 signaling promotes invasion and migration of $\mathrm{CD}_{133^{+}}$ovarian cancer stem-like cells via NF-kB-mediated MMP-9 upregulation. Stem Cells 30: 2309-2319, 2012.

36. Elinav E, Nowarski R, Thaiss CA, Hu B, Jin C and Flavell RA Inflammation-induced cancer: Crosstalk between tumours, immune cells and microorganisms. Nat Rev Cancer 13: 759-771, 2013.

37. Grivennikov SI and Karin M: Inflammation and oncogenesis: A vicious connection. Curr Opin Genet Dev 20: 65-71, 2010.

38. Naugler WE and Karin M: NF-kappaB and cancer-identifying targets and mechanisms. Curr Opin Genet Dev 18: 19-26, 2008.

39. Vandermeulen E, Ruttens D, Verleden SE, Vos R, Van Raemdonck DE, Kastelijn EA, Wauters E, Lambrechts D, Nawrot TS, Cox B, et al: Genetic variation in caveolin-1 affects survival after lung transplantation. Transplantation 98: 354-359, 2014.

40. Hu G, Ye RD, Dinauer MC, Malik AB and Minshall RD Neutrophil caveolin-1 expression contributes to mechanism of lung inflammation and injury. Am J Physiol Lung Cell Mol Physiol 294: L178-L186, 2008.

41. Wang XX, Wu Z, Huang HF, Han C, Zou W and Liu J: Caveolin-1, through its ability to negatively regulate TLR4, is a crucial determinant of MAPK activation in LPS-challenged mammary epithelial cells. Asian Pac J Cancer Prev 14: 2295-2299, 2013.

42. Figgins B, Primeaux B, Shank BR, Chen SE, Weber DM and Lu H: Cyclophosphamide desensitization in patients with severe hypersensitivity reactions to bendamustine. J Oncol Pharm Pract: Aug 21, 2019 (Epub ahead of print). doi: 10.1177/1078155219867127.

43. Liu M, Hales BF and Robaire B: Effects of four chemotherapeutic agents, bleomycin, etoposide, cisplatin, and cyclophosphamide, on DNA damage and telomeres in a mouse spermatogonial cell line. Biol Reprod 90: 72, 2014. 